\title{
Dr. Miguel Madero Pinzón
}

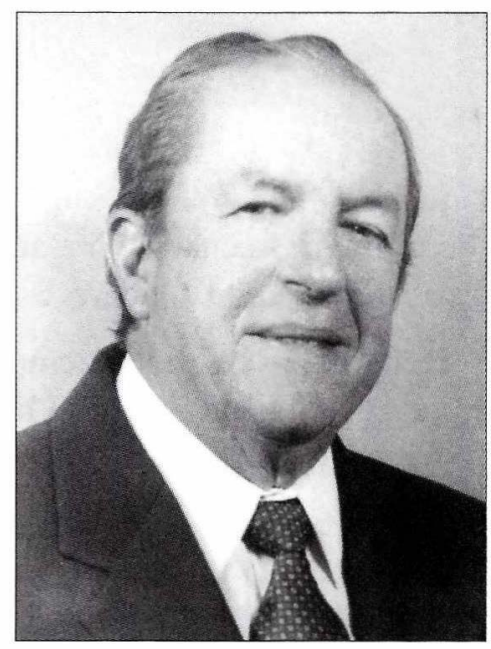

* 5 de mayo de 1938

+ 21 de marzo de 2011

Constituye una enorme pérdida para esta comunidad universitaria, así como para la profesión médica de Colombia y muy particularmente para los especialistas en cirugía cardiovascular, la desaparición de nuestro compañero y amigo por más de cincuenta años, el profesor y doctor Miguel Madero Pinzón.

Continuaremos viéndolo y sintiéndolo en estos claustros -y en la Clínica de Marly su segundo hogar profesional- como un ejemplo de dedicación a sus pacientes, a sus estudiantes y a sus colegas hasta el último minuto de su vida. Siempre discreto y valiente para enfrentar silenciosamente una penosa enfermedad crónica, sin quejarse a nadie, ni dejar de cumplir con su vocación. Vale la pena anotar aquí algo sobre lo cual, apenas si nos hemos enterado después de su fallecimiento y es que aquejado por la leucemia, le solicitó a su médico una reserva absoluta sobre este proceso, que no se lo comunicó inicialmente, ni siquiera a su familia.

Además de su inteligencia, vocación, honestidad y señorío, quienes estuvimos cerca de él pudimos apreciar otras facetas como por ejemplo su humor socarrón, algunos de sus curiosos hábitos, preferencias y rituales en la vida cotidiana, que lo muestran como un ser sensible y con ciertas originalidades peculiares que quisiera no dejar perder en el olvido, porque constituyen aspectos muy humanos de su entraña y su autenticidad.

Permítanme que como amigo que tuve el gusto de tratarlo por muchos años, entresaqué algunas perlas de su perfil de personalidad a partir de mis propios testimonios y por supuesto de sus hijos, amigos y compañeros de golf, y algunos otros de sus colegas. Presentamos estas viñetas como un cariñoso y respetuoso florilegio. 
- Por parte de una de sus hijas, que evoca una tarde en la que él la llevó a toros y un amigo le preguntó: ¿Qué estudia tu hija? El contestó: arquitectura, cuando en realidad ella había cursado ya cinco semestres de ingeniera industrial. "No tengo que decir que lloré de la rabia toda la tarde".

Otro testimonio:

- "Mi papá siempre llegó tarde a jugar golf en el Club San Andrés. Y sin importarle la hora de la llegada tarde siempre salía de primero, lo cual dió lugar a que un consocio le hiciera este versón: "Si quieres salir primero apúntate con Madero".

- En Marly con sus compañeros de almuerzo colaboró siempre en el famoso "Club del Vino". Escrupulosamente aportó siempre su cuota, sin probar el licor. El único "licor que lo sedujo fue American Wine, es decir la famosa Coca-Cola".

- Sus compañeros de mesa, recuerdan también que solía devolver los platos del almuerzo por no tolerar que el arroz fuese mezclado con otros alimentos. Las meseras, entre sorprendidas y sonrientes, tenían que llevarse el plato, separar el arroz y volverlo a atender a su gusto.

- En más de una ocasión no pudo controlar su explosión temperamental, por el famoso plato de arroz, pero para ser justos digamos que en los últimos años adornó su temperamento con una sonrisa de asceta benévolo.

- Y para terminar con las tertulias de Marly, vaya esta muestra de la finura y propiedad de sus piropos: a una bella colega compañera de mesa, un día muy eufórico le dijo: "a pesar de la edad que tienes te ves muy bien".

Bastan aquí estas cariñosas evocaciones para que siempre recordemos al niño que nació el 5 de mayo de 1938. Se especializó en cirugía cardiovascular en Baylor University de Houston, Texas. Fue Profesor Titular de cirugía cardiovascular de la Universidad del Rosario y de la Fundación Universitaria de Ciencias de la Salud. Ingresó como miembro de número de la Sociedad de Cirugía de Bogotá en 1978 y fue varias veces miembro de su Junta Directiva. Fue director científico de la Clínica de Marly durante diez años, jefe del servicio de cirugía del Hospital de San José y director de la División de Publicaciones de la Fundación Universitaria de Ciencias de la Salud. Perteneció a las Sociedades Colombianas de Cirugía, Cardiología, Cirugía Cardiovascular, Vascular Periférica y Cirugía General. Fue miembro del Colegio Americano de Cirujanos y de la Sociedad Venezolana de Cirugía Cardiovascular. Publicó varios artículos sobre enfermedades quirúrgicas del corazón y grandes vasos.

Falleció en Bogotá el 21 de marzo de 2011.

Se queda con nosotros el docto profesor, el amigo, el padre, el esposo ejemplar y el niño y cirujano cardiovascular de grandes afectos.

Luis Carlos Taborda Ramirez MD

Miembro Honorario de la Sociedad de Cirugía de Bogotá 